\title{
BIOACTIVITIES OF EXTRACTS FROM THE MARINE SPONGE Halichondria panicea
}

\section{Purushottama GB (1), Venkateshvaran K (1), Pani Prasad K (2), Nalini P (2)}

(1) Laboratory of Aquatic Biotoxinology, Central Institute of Fisheries Education, Mumbai, India; (2) Department of Aquatic Animal Health Management, Central Institute of Fisheries Education, Mumbai, India.

ABSTRACT: In the present study, we screened the biological activity of extracts from the marine sponge Halichondria panicea collected in the Arabian Sea. Crude toxin was obtained by methanol, chloroform-methanol (2:1) and aqueous extraction. Subsequently, the protein concentration of each crude extract was determined. The impact of both sponge methanolic and aqueous extracts was found to increase activities of $\mathrm{Na}^{+}-\mathrm{K}^{+}$ATP-ase and $\mathrm{Mg}^{++}$ATP-ase. In the case of chloroform-methanol extract, higher concentrations increased acetylcholine esterase (AchE) activity. The methanolic and chloroform-methanol extracts exhibited hemolytic activity on chicken and human erythrocytes, whereas the aqueous extract failed to do so. Methanol and aqueous extracts produced an immunostimulating effect and all extracts revealed angiogenic activity. The aqueous extract yielded nine bands by SDS-PAGE on $12 \%$ gel.

KEY WORDS: Halichondria panicea, phagocytosis, neuromodulation, hemolysis, angiogenesis.

CONFLICTS OF INTEREST: There is no conflict.

\section{CORRESPONDENCE TO:}

K. VENKATESHVARAN, Aquatic Biotoxinology Laboratory, Central Institute of Fisheries Education, Fisheries University Road, Seven Bungalows, Andheri (W), Versova, Mumbai, 400061, India. Phone: +9122 26361446 / 7. Fax: +9122 2636 1573. Email: venkateshvaran@gmail.com. 


\section{INTRODUCTION}

Sponges are simple multicellular sessile animals with no true tissue layers or organs (1). They populate tropical and subtropical benthic marine habitats but are also found at higher latitudes and even in freshwater lakes and streams (2). As sessile filter feeders, they pump large volumes of water through a specialized canal system, known as its aquiferous system (1). Marine sponges are a rich source of structurally novel and biologically active metabolites (3). Over $60 \%$ of potentially useful bioactive compounds discovered so far from living organisms have been obtained from marine fauna, $70 \%$ of which comes from sponges (4). There are approximately 15,000 different species of sponges throughout the globe, 150 of which occur in freshwater, but only about 17 present commercial value for traditional use, including the cosmetic industry. A total of 486 sponge species have been found in Indian waters (5).

The sponge class Demospongiae is known for producing the largest number and diversity of secondary metabolites isolated from marine invertebrates (6). There is a worldwide interest in marine natural products as one of the few de novo sources of drug discovery (7). However, the bioactive potential of compounds from Indian sponges has been little studied. Therefore, the present study comprises an initial effort to assess the bioactivity of secondary metabolites from the marine subtidal sponge Halichondria panicea (Demospongiae class, Halichondrida order, Halichondriidae famaily).

\section{MATERIALS AND METHODS}

\section{Sponge Collection}

The sponge Halichondria panicea was collected from subtidal areas of the Arabian Sea at Mumbai, India (latitude $18.55 \mathrm{~N}$ and longitude $72.54 \mathrm{E}$ ). Animals were taken alive to the laboratory in seawater and immediately frozen at $-20^{\circ} \mathrm{C}$ until use.

\section{Preparation of Sponge Extracts}

Crude toxin was extracted following the method of Braekman et al. (8) with some modifications. To $10 \mathrm{~g}$ of dried sponge sample, $200 \mathrm{~mL}$ of methanol and chloroformmethanol (2:1) as well as deionized water were added and kept standing for five hours. Solvents were then removed, by squeezing sponge samples, and filtered through Whatman filter paper number 1 . The remaining solvent was evaporated at low pressure using a Buchi Rotavapor ${ }^{\circledR}$ R-200 (USA) at $45^{\circ} \mathrm{C}$. The resultant 
compound was finally dried in a vacuum desiccator and stored at $4^{\circ} \mathrm{C}$ in a refrigerator for further use as crude-methanolic or chloroform-methanolic extracts. The aqueous extract of sponges was prepared by squeezing sand-free specimens in triple distilled water. The resultant solution was filtered and dialyzed by using Sigma (USA) dialysis membrane-500 (average flat width: $24.26 \mathrm{~mm}$; average diameter: $14.3 \mathrm{~mm}$; approximate capacity: $1.61 \mathrm{~mL} / \mathrm{cm}$ ) against D-glucose to remove excessive water. Then, the supernatant obtained was lyophilized (FreeZone® Freeze Dry Systems, Labconco, USA) and stored at $4{ }^{\circ} \mathrm{C}$ in a refrigerator for subsequent use as crude aqueous extract.

\section{Partial Purification}

Crude extracts were fractionated using a locally made DEAE-cellulose column (29 $\mathrm{x}$ $2.3 \mathrm{~cm}$ ). Ten adsorbed fractions (designated $\mathrm{F} 1$ to $\mathrm{F} 10$ ), $15 \mathrm{~mL}$ each, were submitted to step-gradient elution of 0.1 to $1.0 \mathrm{M} \mathrm{NaCl}$ in phosphate buffered saline (PBS) solution, $\mathrm{pH}$ 7.4. Moreover, five 15-mL unabsorbed fractions were also eluted with phosphate buffer, $\mathrm{pH} 7.4$. They were all stored at $4^{\circ} \mathrm{C}$ for later use.

\section{Protein Estimation}

Protein content from crude extracts and fractions was estimated (9).

\section{Neuromodulatory Activity}

$P_{2}$ fraction (mitochondrial nerve endings) from male mouse (20 $\pm 2 \mathrm{~g}$ ) brain was prepared (10). The protein content of the enzyme source was estimated as previously described.

ATP-ase assays for $\mathrm{Na}^{+}-\mathrm{K}^{+}$ATP-ase activity and $\mathrm{Mg}^{++}$ATP-ase activity were conducted following the inorganic phosphate method (11). Control experiments were also run simultaneously with $100 \mu \mathrm{L}$ of triple distilled water instead of extracts/fractions. Enzyme activity was expressed as micromoles of inorganic phosphate per miligram per hour.

AChE inhibitory activity was calorimetrically measured (12). Briefly, to $3 \mathrm{~mL}$ of $0.1 \mathrm{M}$ phosphate buffer, $\mathrm{pH} 8.0$, contained in each tube, $0.1 \mathrm{~mL}$ of enzyme source $(2 \% \mathrm{w} / \mathrm{v}$ homogenate) was added and stirred. Then, $100 \mu \mathrm{L}$ of 0.01 DNTB (0 5-5-dithiobis-2 nitrobenzoic acid) was added and the initial color was spectrophotometrically 
measured at $412 \mathrm{~nm}$. The reaction was started by adding $20 \mu \mathrm{L}$ of acetylthiocholine iodide $(\mathrm{ATCl})(0.075 \mathrm{M})$ as substrate to each tube; then, the reaction was allowed to continue for 15 minutes at room temperature. The developed color was spectrophotometrically measured at $412 \mathrm{~nm}$ and the inhibitory activity was calculated.

\section{Hemolytic Activity}

The hemolysis of crude toxin on chicken and human red blood cells (RBC) was tested by a micro-hemolytic method (13). Chicken and human blood were obtained, respectively, from a nearby slaughterhouse and Sheena Clinic, Andheri, Mumbai, India using EDTA solution (2.7 $\mathrm{g}$ in $100 \mathrm{~mL}$ of distilled water) as an anticoagulant at $5 \%$ of the blood volume and brought to the laboratory. A $1 \%$ erythrocyte suspension was prepared by adding $99 \mathrm{~mL}$ of PBS, $\mathrm{pH} 7.4$, to $1 \mathrm{~mL}$ of packed RBC (14). The micro-hemolytic test was performed on 96-well U-bottom microtiter plates. Serial twofold dilutions of the extracts were carried out in $100 \mu \mathrm{L}$ of PBS, pH 7.4. In controls, to $3 \%$ RBC suspension, $100 \mu \mathrm{L}$ of distilled water was added, which served as positive control and an equal amount of PBS, pH 7.4, was negative control. The plate was gently shaken and allowed to stand for two hours at room temperature; then the results were recorded. Uniform red color suspension in the wells was considered positive hemolysis while sedimentation on the bottom was considered lack of hemolysis.

\section{Phagocytosis}

Immunomodulatory activity was analyzed by a slide method through in vitro phagocytosis of Candida albicans by polymorphonuclear cells (PMN) (15).

\section{Chorioallantoic Membrane (CAM) Assay}

Nine-day-old fertilized chicken eggs were selected and small holes of $1.0 \mathrm{~cm}^{2}$ were made in their shells. Next, air was sucked out from the eggs to bring their membranes down (16). Through each opening, a sterile disc of methylcellulose containing concentration of $40 \mu \mathrm{g}$ and $80 \mu \mathrm{g} / \mathrm{mL}$ of crude extracts was placed inside the egg at the junction of two blood vessels. Subsequently, the opening was resealed with tape and the eggs were incubated at $37^{\circ} \mathrm{C}$ in a BOD incubator for 72 hours. The 
holes were then reopened and vessel formation was observed in terms of number and caliber, and finally compared with eggs containing discs without any lyophilized crude extract. Positive controls were also maintained in the same conditions.

\section{SDS-PAGE}

Crude extracts were submitted to electrophoresis in $12 \%$ polyacrylamide slab gels to analyze their protein profile (17).

\section{RESULTS}

\section{Preparation of Sponge Extract}

From an initial 10-g sample of dried sponge tissue, methanolic and chloroformmethanol (2:1) extraction, yielded, respectively 1.970 and $0.520 \mathrm{~g}$ of crude toxin, while aqueous extraction yielded $3.0 \mathrm{~g}$.

\section{Protein Estimation}

The crude protein contents were found to be 0.096 and $0.192 \mathrm{mg} / \mathrm{mL}$, respectively, in methanolic and chloroform-methanol extracts, and $0.124 \mathrm{mg} / \mathrm{mL}$ in aqueous extract. It ranged from below detectable levels to $0.014 \mathrm{mg} / \mathrm{mL}$ in methanolic extract fractions and from below detectable levels to $0.002 \mathrm{mg} / \mathrm{mL}$ in aqueous extract.

\section{Neuromodulatory Activity}

$\mathrm{Na}^{+}-\mathrm{K}^{+}$ATP-ase activity was inhibited by methanolic (4.07 to $354.24 \%$ ), chloroformmethanol (319.79 to $242.61 \%$ ) and aqueous (271.59 to $272.06 \%$ ) extracts. However, in all three cases, the activity was enhanced at doses from 250 to $1,000 \mu \mathrm{g}$.

The methanolic extract elevated $\mathrm{Mg}^{++}$ATP-ase activity by $285.0 \%$ at $250 \mu \mathrm{g} / \mathrm{mL}$ concentration, but inhibited it by up to $135.62 \%$ at $750 \mu \mathrm{g} / \mathrm{mL}$ and, finally, at 1,000 $\mu \mathrm{g} / \mathrm{mL}$ concentration augmented the activity again. The chloroform-methanol extract elevated $\mathrm{Mg}^{++}$ATP-ase activity by $338.64 \%$ at a lower concentration of $250 \mu \mathrm{g} / \mathrm{mL}$; however, it inhibited the activity by up to $188.70 \%$ at $750 \mu \mathrm{g} / \mathrm{mL}$, and at $1,000 \mu \mathrm{g} / \mathrm{mL}$ increased the activity. The aqueous extract elevated $\mathrm{Mg}^{++}$ATP-ase activity up to 355.87 and $355.64 \%$, respectively, at concentrations of 250 and $500 \mu \mathrm{g} / \mathrm{mL}$, but inhibited the activity, up to $307.45 \%$, at higher concentrations (Figures 1 to 3 ).

Methanolic extract inhibited AChE activity up to $-93.10 \%$ at $250 \mu \mathrm{g}$ and $500 \mu \mathrm{g} / \mathrm{mL}$, but elevated the activity by $31.03 \%$ at the higher concentration of $1,000 \mu \mathrm{g} / \mathrm{mL}$. $A$ 
similar trend was found in the chloroform-methanol extract, in which inhibition was observed at the lower concentration of $250 \mu \mathrm{g} / \mathrm{mL}(-13.79 \%)$, while increase was registered at higher concentrations of 500,750 and $1,000 \mu \mathrm{g} / \mathrm{mL}$ (respectively, 17.24, 27.58 and $106.89 \%)$. In the aqueous extract, the inhibitory effect of $-20.68 \%$ was observed from lower to higher concentrations (Figures 4 to 6 ).

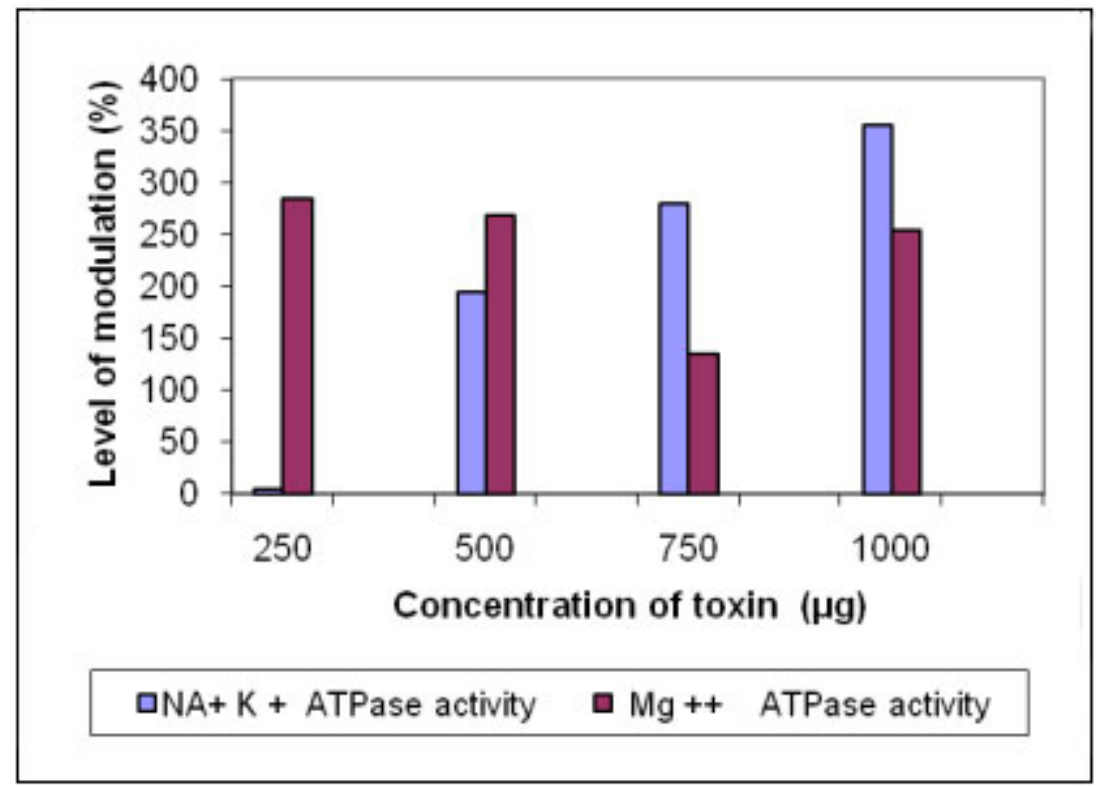

Figure 1. Modulation of $\mathrm{Na}^{+}-\mathrm{K}^{+}$ATP-ase and $\mathrm{Mg}^{++}$ATP-ase activity by the methanolic extract of Halichondria panicea.

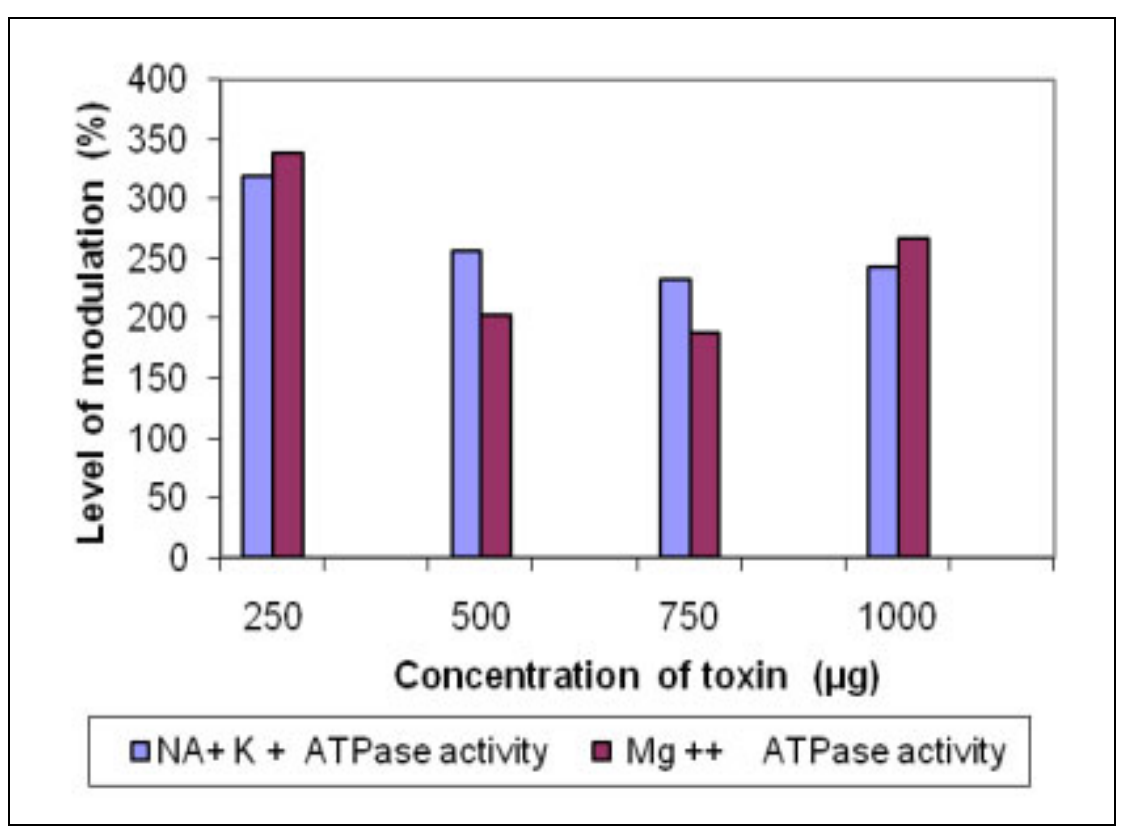

Figure 2. Modulation of $\mathrm{Na}^{+}-\mathrm{K}^{+}$ATP-ase and $\mathrm{Mg}^{++}$ATP-ase activity by the chloroform-methanol (2:1) extract of Halichondria panicea. 


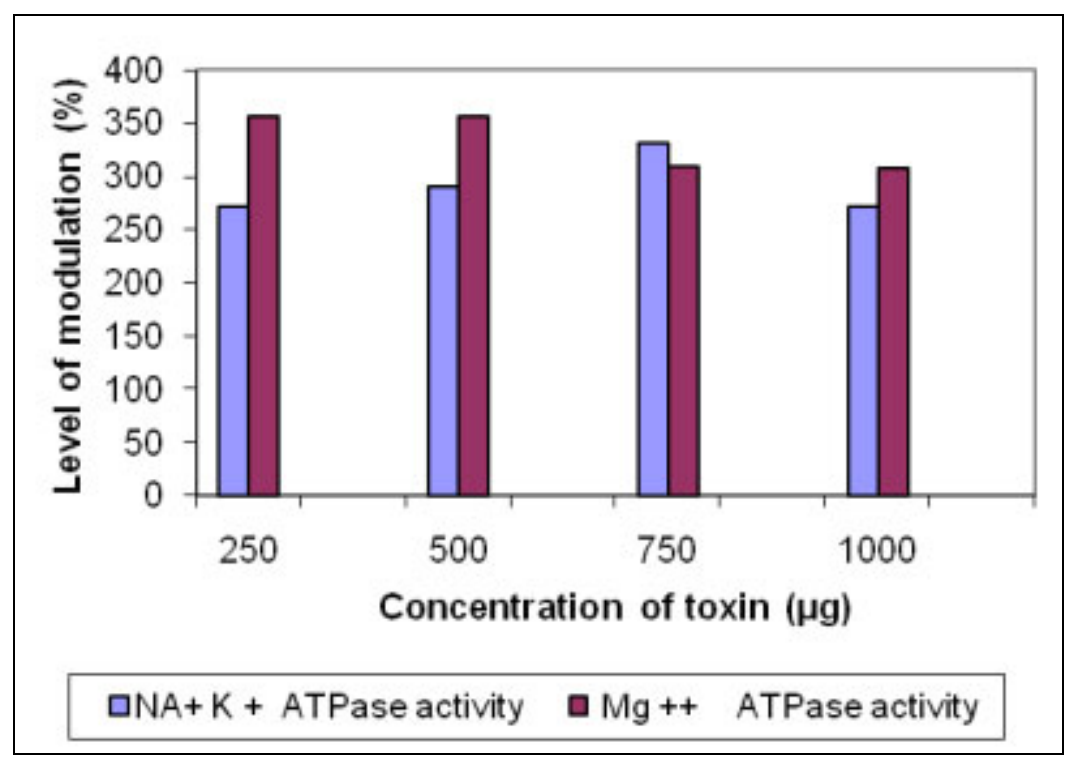

Figure 3. Modulation of $\mathrm{Na}^{+}-\mathrm{K}^{+} \mathrm{ATP}$-ase and $\mathrm{Mg}^{++}$ATP-ase activity by the aqueous extract of Halichondria panicea.

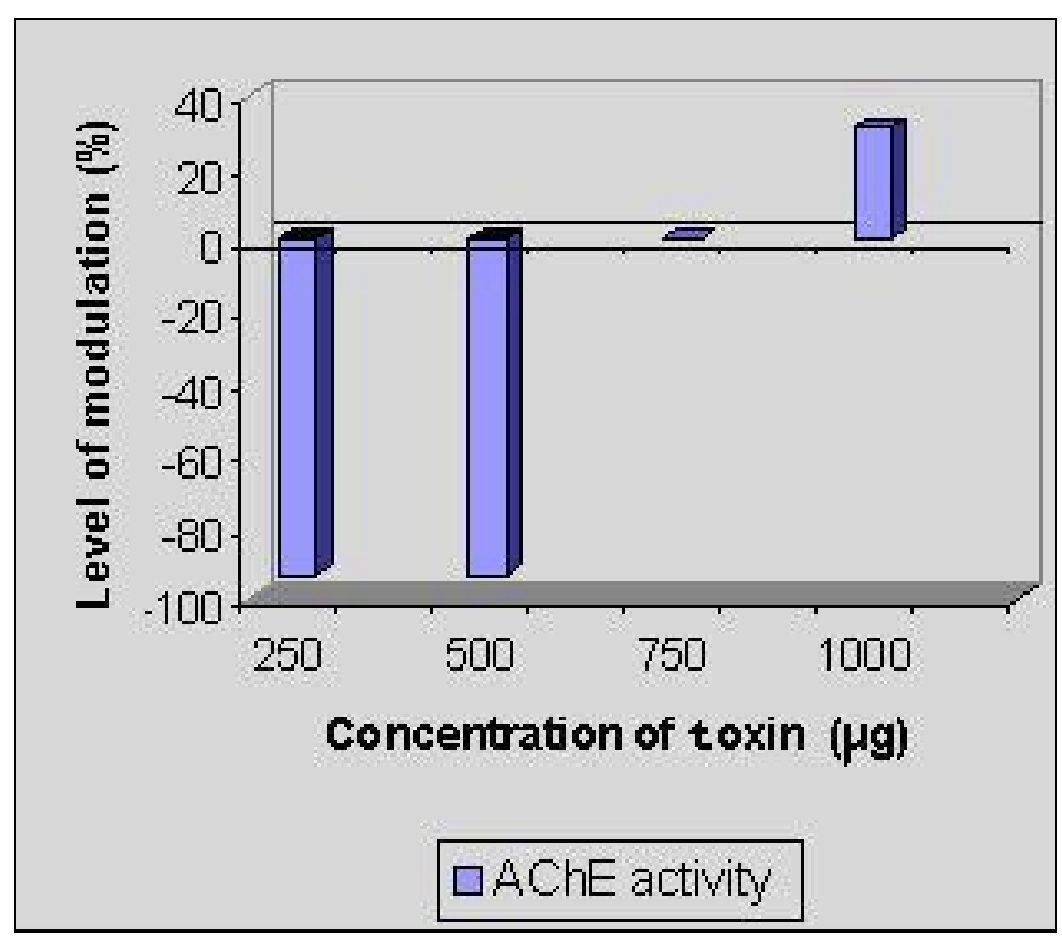

Figure 4. Modulation of AChE activity by the methanolic extract of Halichondria panicea. 


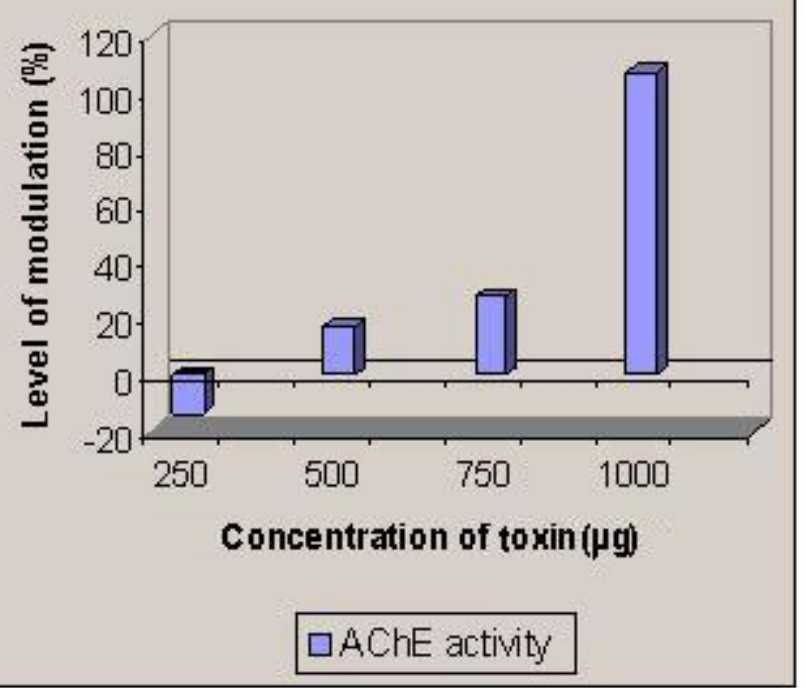

Figure 5. Modulation of AChE activity by the chloroform-methanol (2:1) extract of Halichondria panicea.

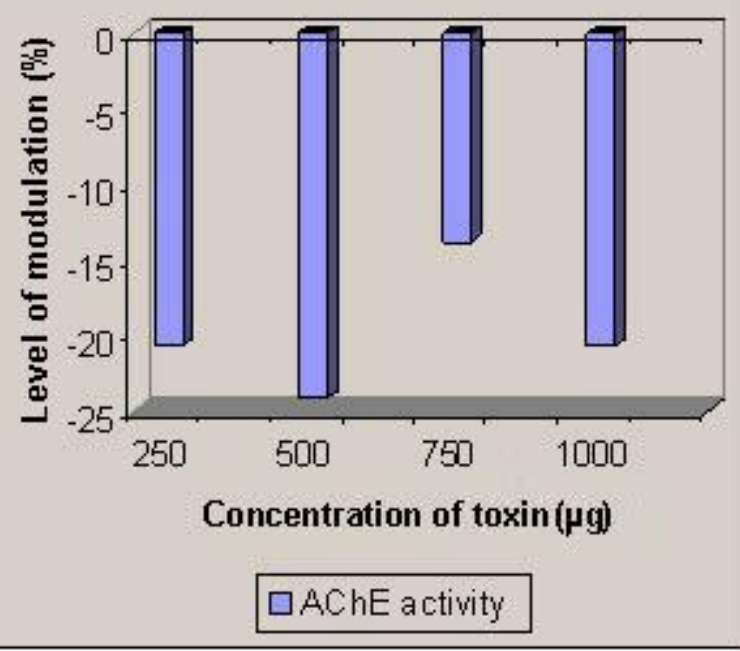

Figure 6. Modulation of $\mathrm{AChE}$ activity by the aqueous extract of Halichondria panicea.

\section{Hemolytic Assay}

In chicken blood, crude methanolic and chloroform-methanol extracts induced pronounced hemolysis with specific hemolytic activity of 333.33 in each case. They also lysed human blood, with respective specific hemolytic activities of 20.83 and 10.41. The aqueous extract failed to elicit hemolysis in either chicken or human blood. 
F6 fraction of the methanolic extract induced partial hemolysis in both chicken and human blood (specific hemolytic activity 571.42). All other fractions failed to induce hemolysis in chicken or human blood (Tables 1 and 2).

Table 1. Hemolytic activity of Halichondria panicea crude toxin at $5 \mathrm{mg} / \mathrm{mL}$ in chicken and human erythrocytes

\begin{tabular}{|c|c|c|c|c|c|c|c|c|}
\hline \multirow{3}{*}{$\begin{array}{c}\text { Serial } \\
\mathrm{n} .\end{array}$} & \multirow{3}{*}{$\begin{array}{l}\text { Type of } \\
\text { extract }\end{array}$} & \multirow{3}{*}{$\begin{array}{l}\text { Protein } \\
(\mathrm{mg})\end{array}$} & \multicolumn{6}{|c|}{ Blood } \\
\hline & & & \multicolumn{3}{|c|}{ Chicken } & \multicolumn{3}{|c|}{ Human } \\
\hline & & & $\begin{array}{l}\text { Total } \\
\text { hemolysis } \\
\text { (up to } \\
\text { dilutions) }\end{array}$ & $\begin{array}{c}\text { Hemolytic } \\
\text { titer }\end{array}$ & $\begin{array}{c}\text { Specific } \\
\text { hemolytic } \\
\text { activity } \\
(\mathrm{HT} / \mathrm{mg})\end{array}$ & $\begin{array}{c}\text { Total } \\
\text { hemolysis } \\
\text { (up to } \\
\text { dilutions) }\end{array}$ & $\begin{array}{c}\text { Hemolytic } \\
\text { titer }\end{array}$ & $\begin{array}{c}\text { Specific } \\
\text { hemolytic } \\
\text { activity } \\
(\mathrm{HT} / \mathrm{mg})\end{array}$ \\
\hline 1 & Methanol & 0.096 & 5 & 32 & 333.33 & 1 & 2 & 20.83 \\
\hline 2 & $\begin{array}{l}\text { Chloroform- } \\
\text { methanol } \\
(2: 1)\end{array}$ & 0.192 & 6 & 64 & 333.33 & 1 & 2 & 10.41 \\
\hline 3 & Aqueous & 0.124 & 0 & 0 & 0 & 0 & 0 & 0 \\
\hline
\end{tabular}

Table 2. Hemolytic activity of methanolic and aqueous fractions of Halichondria panicea on chicken erythrocytes

\begin{tabular}{|c|c|c|c|c|c|c|c|c|c|}
\hline \multirow{3}{*}{$\begin{array}{c}\text { Serial } \\
\mathrm{n} .\end{array}$} & \multirow{3}{*}{$\begin{array}{l}\text { Type of } \\
\text { solution }\end{array}$} & \multicolumn{8}{|c|}{ Chicken } \\
\hline & & \multicolumn{4}{|c|}{ Methanolic } & \multicolumn{4}{|c|}{ Aqueous } \\
\hline & & $\begin{array}{c}\text { Protein } \\
(\mathrm{mg})\end{array}$ & $\begin{array}{l}\text { Total } \\
\text { hemolysis } \\
\text { (up to } \\
\text { dilution) }\end{array}$ & $\begin{array}{c}\text { Hemolytic } \\
\text { titer }\end{array}$ & $\begin{array}{c}\text { Specific } \\
\text { hemolytic } \\
\text { activity } \\
(\mathrm{HT} / \mathrm{mg})\end{array}$ & $\begin{array}{l}\text { Protein } \\
(\mathrm{mg})\end{array}$ & $\begin{array}{l}\text { Total } \\
\text { hemolysis } \\
\text { (up to } \\
\text { dilution) }\end{array}$ & $\begin{array}{l}\text { Hemolytic } \\
\text { titer }\end{array}$ & $\begin{array}{c}\text { Specific } \\
\text { hemolytic } \\
\text { activity } \\
\text { (HT/mg) }\end{array}$ \\
\hline 1 & $0.2 \mathrm{M}$ & ND & ND & ND & ND & ND & ND & ND & ND \\
\hline 2 & $0.4 \mathrm{M}$ & ND & ND & ND & ND & ND & ND & ND & ND \\
\hline 3 & $0.6 \mathrm{M}$ & 0.014 & 3 & 8 & 571.42 & 0.002 & ND & ND & ND \\
\hline 4 & $0.8 \mathrm{M}$ & 0.006 & ND & ND & ND & ND & ND & ND & ND \\
\hline 5 & $1.0 \mathrm{M}$ & 0.004 & ND & ND & ND & ND & ND & ND & ND \\
\hline
\end{tabular}

ND: non-detectable 


\section{Phagocytosis}

The methanol extract of Halichondria panicea exerted an immunostimulating effect of 7.57 to $10.30 \%$ magnitude at lower concentrations and a suppressive effect of $6.81 \%$ at higher concentrations. The chloroform-methanol extract had a stimulative activity of up to $12.27 \%$ at a lower concentration $(100 \mu \mathrm{g} / \mathrm{mL})$, but exerted a suppressive activity from 1.91 to $8.24 \%$ at higher concentrations. The aqueous extract exhibited immunostimulation ranging from 1.99 to $10.05 \%$ at concentrations up to $800 \mu \mathrm{g}$, but showed immunosuppressive effects at $1,000 \mu \mathrm{g}$ concentration (Figures 7 to 9).

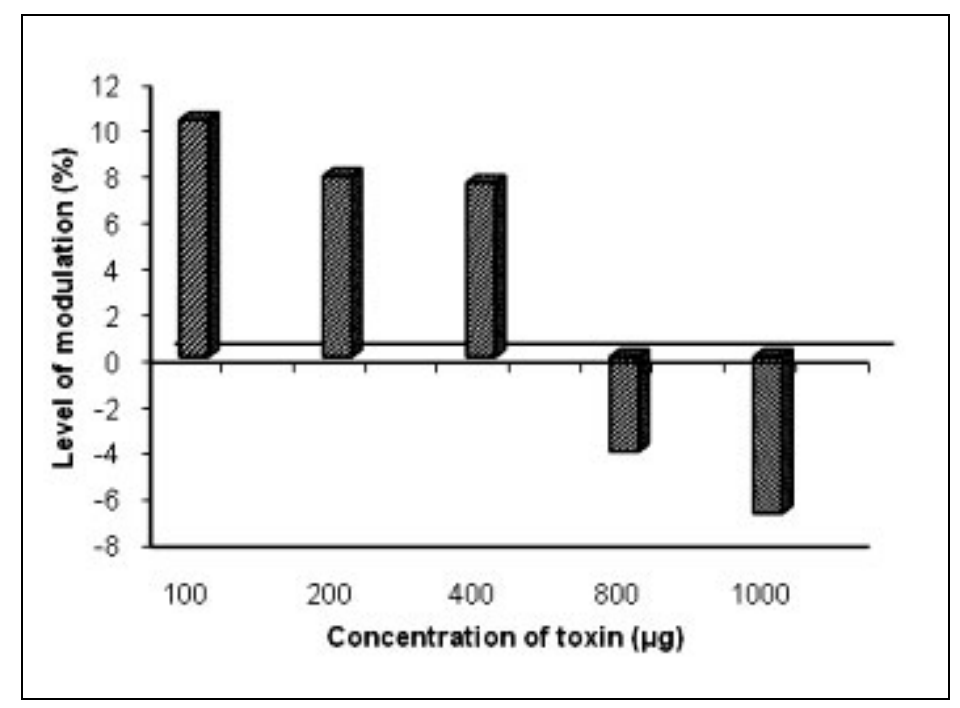

Figure 7. Immunomodulation produced by the methanolic extract of Halichondria panicea.

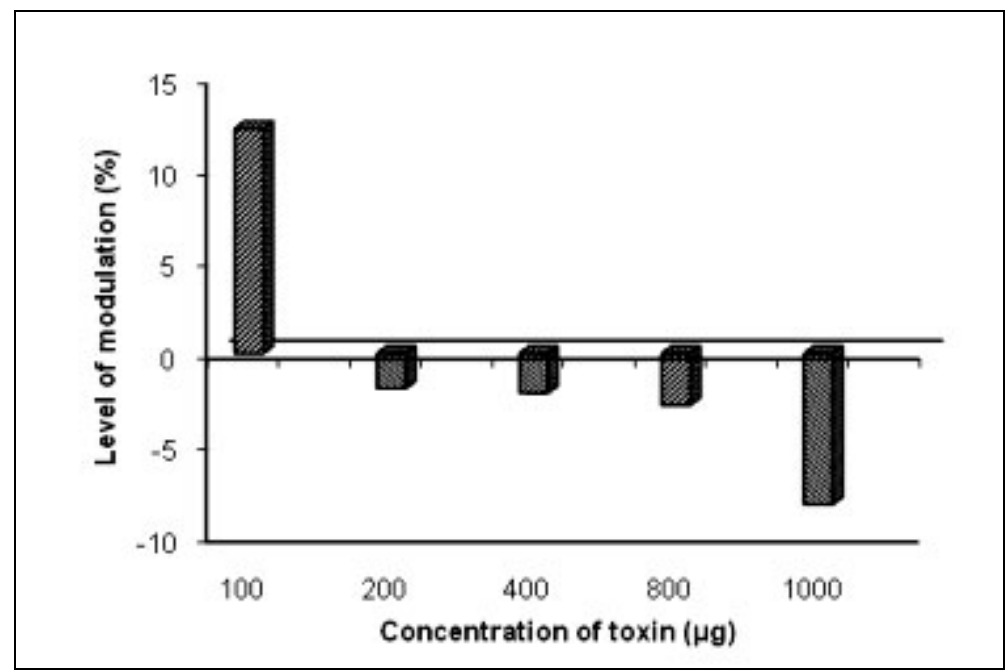

Figure 8. Immunomodulation produced by the chloroform-methanol $(2: 1)$ extract of Halichondria panicea. 


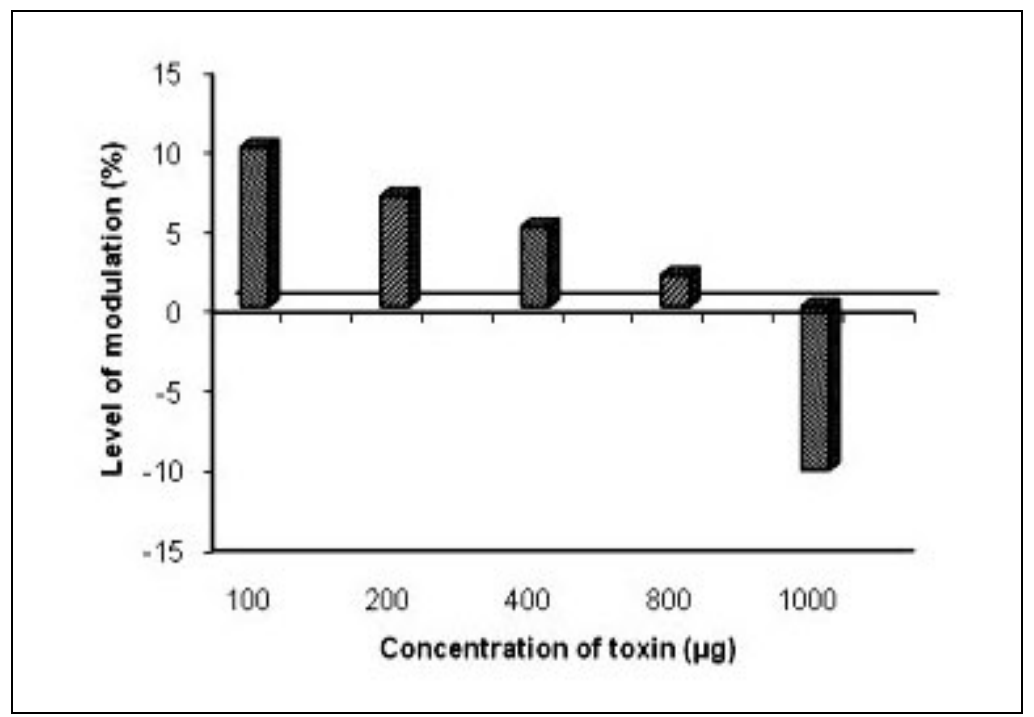

Figure 9. Immunomodulation produced by the aqueous extract of Halichondria panicea.

\section{Chorioallantoic Membrane (CAM) Assay}

Results of the chorioallantoic membrane (CAM) assay are presented in Table 3. All the extracts from Halichondria paincea showed angiogenic activity including increase in thickness of blood vessels compared to the control group at 40 and $80 \mu \mathrm{g}$ doses.

Table 3. Angiogenesis in 9-day-old chicken egg after treatment with methanolic, chloroform-methanol (2:1) and aqueous extracts

\begin{tabular}{|c|c|c|c|}
\hline & \multirow{2}{*}{ Extract type } & \multicolumn{2}{|c|}{ Toxin concentration } \\
\hline & & $40 \mu \mathrm{g} / \mathrm{mL}$ & $80 \mu \mathrm{g} / \mathrm{mL}$ \\
\hline 1 & Aqueous & + & + \\
\hline 2 & Methanol & ++ & +++ \\
\hline 3 & Chloroform-methanol (2:1) & ++ & ++ \\
\hline
\end{tabular}

+: slight; ++: moderate; +++: severe.

\section{SDS-PAGE}

By SDS-PAGE on $12 \%$ gel, crude toxins yielded nine bands in Halichondria panicea aqueous extract, ranging from 14.3 to $116 \mathrm{kDa}$ with three well-defined bands at 19.5 , 39.0 and $66.2 \mathrm{kDa}$ (Figure 10). 


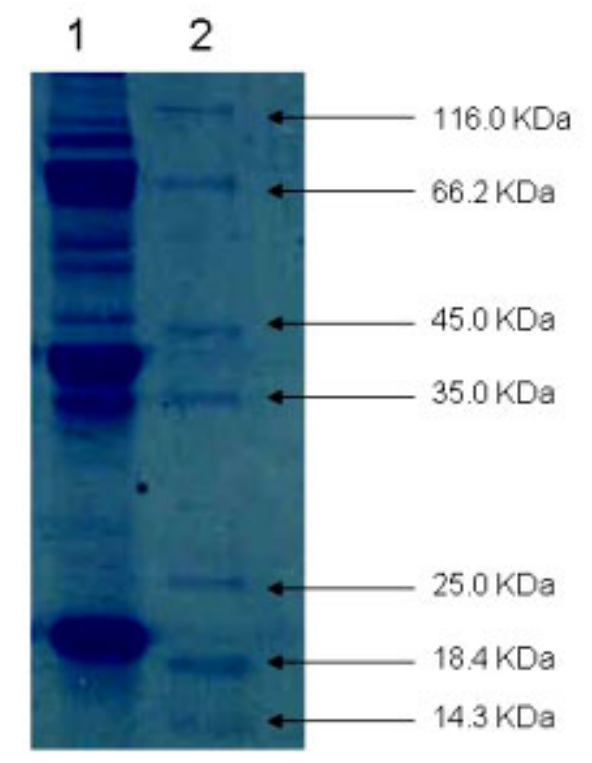

Lane 1: Aqueous extract

Lane 2: Standard molecular weight marker

Figure 10. SDS-PAGE of crude protein extracts of Halichondria panacea.

\section{DISCUSSION}

The amount of crude toxin extracted by lyophilization in the current study was higher compared to those reported in earlier findings. Kerr et al. (18) obtained $1.67 \mathrm{~g}$ of crude extract from $200 \mathrm{~g}$ of Epipolasis sp. and Kijjoa et al. (19) obtained $5.8 \mathrm{~g}$ of crude extract from $490 \mathrm{~g}$ of fresh marine sponge Suberea praetensa.

The crude protein content of the various studied extracts could not be compared with previous studies because similar data on protein contents of sponge toxins are not available in the literature.

The present results on AChE activity of Halichondria panicea extracts correspond to earlier findings of Elancheran (20), who reported elevated AChE activity due to higher doses of tetrodotoxin. Wankhede (21) observed similar neuroinhibitory activity by bile extracts of freshwater carps on the $\mathrm{Na}^{+}-\mathrm{K}^{+}$ATP-ase enzyme system in mammalian models The ATP-ase enzyme system is widely accepted as a structure that employs part of the free energy from ATP hydrolysis for active transport of $\mathrm{Na}^{+}$$\mathrm{K}^{+}$. Lehinnger (22) found that metabolic stimulation provoked by ionic movement at the membrane level results from a series of reactions that lead to accumulation of $\mathrm{ADP}$ and $\mathrm{Pi}$ (inorganic phosphate), which play an important role in regulating respiration. Augmented ADP concentration intensifies mitochondrial respiration that, in turn, increases oxygen consumption and accelerates ATP biosynthesis. 
Schmitz et al. (23) reported the hemolytic activity of halitoxin from sponges of the genus Haliclona. Similarly, Mebs et al. (24) observed hemagglutination and hemolytic activity of aqueous extracts from 48 tropical sponge species. Malovrh et al. (25) described cytotoxic and cytolytic activities of polymeric alkylpyridinium salts (polyAPS) from the marine sponge Reniera sarai, which they inferred were due to their detergent-like structure and behavior in aqueous solutions.

Indap and Pathare (26) reported hemolytic activity as $\mathrm{HD}_{50}$ at $<2 \mathrm{mg} / \mathrm{mL}$ in the chloroform extract from Tethya sp. Moreover, Fusetani et al. (27) and Makarieva et al. (28) reported that sterol derivatives from halichondriid sponges, namely halistanol sulfates and sokotrasterol sulfates, possessed hemolytic activity. Abas et al. (4) screened marine sponges from Malaysian waters and reported cytotoxic activity as well as an effect on liver-metabolizing enzymes. Sepčić et al. (3) described significant levels of hemolytic and hemagglutinating activities of Reniera sarai extracts compared to the moderate hemolytic activity of extracts from Saracotragus muscarum and Aplysina aerophoba.

Thus, Halichondria panicea appears to be a candidate for further studies on analgesic or antineoplastic activities of its secondary metabolites in terms.

The present study revealed that the three crude extracts of Halichondria panicea had immunostimulative effects at lower concentrations. However, at higher concentrations, they exhibited immunosuppressive effects. This aspect requires further studies in greater detail, since, according to Hudson and Hay (29), immunomodulation by marine toxins has been a poorly studied subject.

Wound healing is a process that is fundamentally a connective tissue response. The initial stage of this process involves an acute inflammatory phase followed by synthesis of collagen and other extracellular macromolecules that are later remodeled to form scar tissue (30). Extensive turnover (degradation and biosynthesis) of the connective tissue is evident, requiring the action of proteolytic enzymes such as collagenase and cathepsins.

Angiogenesis, the growth of new capillary blood vessels, is important in normal processes such as embryo development, corpus luteum formation and wound healing. It is also a component in pathological processes including chronic inflammation, certain immune responses and neoplasia (31). Deo (32) had demonstrated very similar angiogenesis activity by mucous extracts of two marine catfishes, Arius dussumieri and Osteogeneiosus militaris. 
SDS-PAGE analysis during the present study revealed medium-sized proteins in crude toxin from the aqueous extract. Prominent bands indicated proteins of 19.5, 39.0 and $66.2 \mathrm{kDa}$ in the aqueous extract of Halichondria panicea. Corresponding data on SDS-PAGE is not available in the literature for comparison; further study on the main compound responsible for the bioactivity of the marine sponge Halichondria panicea will be necessary.

\section{REFERENCES}

1. Bergquist PR. Sponges. California: University of California Press; 1978. 268 p.

2. Hooper JNA, Van Soest RWM. Systema Porifera: a guide to the classification of sponges. New York: Plenum Publishers; 2002. 1 vol. p. 721-3.

3. Sepčić K, Batista U, Vacelet J, Macek P, Turk T. Biological activities of aqueous extracts from marine sponges and cytotoxic effects of 3-alkylpyridinium polymers from Reniera sarai. Comp Biochem Physiol. 1997;117(1):47-53.

4. Abas $\mathrm{HH}$, Zulfigar $\mathrm{Y}$, Chan KL. Cytotoxicity and drug metabolism screening of several marine sponges from Pulau Pasir, Kedah and Pulau Aur, Johor. Asean Review of Biodiversity and Environmental Conservation (ARBEC). 1999.

5. Thomas PA. Porifera. In: Alfred JRB, Das AK, Sanyal AK, editors. Faunal diversity in India. Calcutta: ENVIS Central Zoological Survey of India; 1998. p. 28-36.

6. Newbold RW, Jensen PR, Fenical W, Pawlik JR. Antimicrobial activity of Caribbean sponge extracts. Aquat Microb Ecol. 1999;19:279-84.

7. McConnell OJ, Longley RE, Koehn FE. The discovery of marine natural products with therapeutic potential. Biotechnology. 1994;26:109-74.

8. Braekman JC, Daloze D, Stoller C, Van Soest RWM. Chemotaxonomy of Agelas (Porifera: Demospongiae). Biochem Syst Ecol. 1992;20(5):417-31.

9. Peterson GL. A simplification of the protein assay method of Lowry et al. which is more generally applicable. Anal Biochem. 1977;83(2):346-56.

10. Green DE, Lester RL, Ziegler DM. Studies on the mechanism of oxidative phosphorylation. I. Preparation and properties of a phosphorylating electron transfer practicle from beef heart mitochondria. Biochem Biophys Acta. 1957;23(3):516- 24.

11. Fiske $\mathrm{CH}$, Subbarow $\mathrm{YT}$. The colorimetric determination of phosphorus. J Biol Chem. 1925;66(2):375-400. 
12. Ellman GL, Courtney KD, Andres V Jr, Feather-Stone RM. A new and rapid colorimetric determination of acetylcholinesterase activity. Biochem Pharmacol. $1961 ; 7: 88-95$.

13. Prasad KP, Venkateshvaran K. Microhemolytic assay. In: Venkateshvaran K, Prasad KP, editors. Training manual on advance techniques in marine biotoxinology. India: CAS in Fishery Science, Central Institute of Fisheries Education; 1997. p. 41-2. 14. Kwapinski JB. Methods of serological research. New York: John Wiley \& Sons, Inc.; 1965. 526 p.

15. Kulkarni SR, Karnade VS. Study of the immunostimulant activity of naphthoquinone extract of leaves of Lawsonia alba Linn. Indian Drugs. 1998;35(7):427-34.

16. Lobb RR, Alderman EM, Fett JW. Induction of angiogenesis by bovine brain derived class 1 heparin-binding growth factor. Biochemistry. 1985;24(19):4969-73.

17. Lamemli UK. Cleavage of structural proteins during the assembly of the head of bacteriophage T4. Nature. 1970;227(5259):680-8.

18. Kerr RG, Foss C, Matsunaga S, Fusetani N. Isolation and structure elucidation of epipolasterol and 22,23- dihydroepipolasterol from marine sponge Epipolasis sp. Comp Biochem Physiol. 1997;117(4):561-3.

19. Kijjoa A, Watanadilok R, Sonchaeng P, Silva AM, Eaton G, Herz W. 11,17dideoxyagelorin $A$ and $B$, new bromotyrosine derivatives and analogs from the marine sponge Suberea aff. praetensa. Z Naturforsch [C]. 2001;56(11-12):1116-9.

20. Elancheran P. Studies on toxins of certain marine fishes. [Dissertation]. Mumbai: Central Institute of Fisheries Education; 1994. 155 p.

21. Wankhede M. Neuroinhibitory activity of fish bile and ovarian extracts of the Horseshoe Crab. [Dissertation]. Mumbai: Central Institute of Fisheries Education; 1996. 58 p.

22. Lehninger AL. The mitochondrian. New York, Amsterdam: W. A. Benjamin; 1964. $132 \mathrm{p}$.

23. Schmitz FJ, Hollenbeak $\mathrm{KH}$, Campbell DC. Marine natural products: halitoxin, toxic complex of several marine sponges of genus Haliclona. J Org Chem. 1978;43(20):3916-22.

24. Mebs D, Weiler I, Heinke HF. Bioactive proteins from marine sponges: screening of sponge extracts for hemagglutinating, hemolytic, ichthyotoxic and lethal properties and isolation and characterization of hemagglutinins. Toxicon. 1985;23(6):955-63. 
25. Malovrh P, Sepcić K, Turk T, Macek P. Characterization of hemolytic activity of 3alkylpyridinium polymers from the marine sponge Reniera sarai. Comp Biochem Physiol C Pharmacol Toxicol Endocrinol. 1990; 124(21):221-6.

26. Indap MM, Pathare SP. Cytotoxicity and bioactivity of some marine animals. Indian J Mar Sci. 1998;27:433-7.

27. Fusetani N, Matsunaga S, Konosu S. Bioactive marine metabolites. II Halistanol sulfate, an antimicrobial novel steroid sulfate from sponge Halichondria cf. moorei Bergquist. Tetrahedron Lett. 1981;21:1985-8.

28. Makarieva TN, Shubina LK, Kalinovsky AI, Stonik VA, Elyakov GB. Steroids in Porifera. II: Steroid derivatives from two sponges of the family Halichondriidae sokotrasterol sulfate, a marine steroid with a new pattern of side chain alkylation. Steroids. 1983;42(3):267-81.

29. Hudson L, Hay FC. Practical immunology. $3^{\text {rd }}$ ed. Oxford: Blackwell Scientific Publication; 1991. $507 \mathrm{p}$.

30. Chithra P, Sajithlal GB, Chandrakasan G. Influence of Aloe vera on collagen characteristics in healing dermal wounds in rats. Mol Cell Biochem. 1998;181(12):71-6.

31. Taylor SL, Folkman J. Protamine is an inhibitor of angiogenesis. Nature. 1982;297:307-12.

32. Deo AD. Ichthyocrinotoxicity of Marine Catfishes of Mumbai Coast. [Dissertation]. Mumbai: Central Institute of Fisheries Education, Mumbai; 2000. 128 p. 